\title{
Meeting of the minds: research priorities for value co-creation in dialogical conferences
}

Joy Parkinson, Department of Marketing, Griffith Business School, Griffith University, Queensland, Australia

Janet Davey, School of Marketing and International Business, Victoria University of Wellington, Wellington, New Zealand

\begin{abstract}
Approach

The growing challenge for service researchers is to generate new theory and knowledge to solve complex problems. Dialogical conferences offer an avenue to develop solutions in response to this challenge. Value co-creation provides a useful lens through which to view dialogical conferences. We draw on Ranjan and Read's (2016) value-in-use and value coproduction and Ramaswamy and Ozcan's (2018) interactive engagement platforms for value co-creation. Mindful of the contributions of both, the paper presents an integrative framework that describes the relationships between the concepts to provide a firm grounding for developing dialogical conferences.

\section{Purpose}

This viewpoint explains the development of the dialogical conference, develops a framework for understanding the social construction of the dialogical conference, and provides research priorities for further developing the practice in the services marketing discipline.
\end{abstract}

\section{Findings}

By mapping value co-creating activities in dialogical conferences according to the APPI framework - artifacts, persons, processes and interfaces - on to value-in-use and value coproduction, we propose a new category of value-in-use, equality, to the conceptualisation of value co-creation outcomes. Equality in contribution, attribution, and effort is underrepresented in value co-creation. 


\section{Originality}

Dialogical conferences are increasingly important for knowledge generation and creating potential for action, yet are underexplored in service research. This paper contributes to the literature by using service logic and dialogical conferences to extend our knowledge of value co-creation interactive platforms and outcomes. Second, we demonstrate the value of dialogical conferences for facilitating meaningful service research and knowledge development. Finally, the authors identify research priorities to encourage further work on extending the understanding and application of dialogical interactive platforms and value cocreation to enable the service community to be responsive in solving complex problems through service offerings.

\section{Keywords}

Dialogical conferences, services, interactive platforms, wicked problems, value co-creation Paper type: Viewpoint 


\section{Meeting of the minds: research priorities for value co-creation in dialogical conferences}

\section{Introduction}

Service researchers are continually being challenged to develop new approaches for generating new theory, knowledge and impact (Anderson and Ostrom, 2015; Brodie, 2017). Service researchers, seeking to solve problems arising from the complexities of human service systems, share theoretical developments and knowledge through presentations at conferences (Davis and Pechmann, 2013). Conferences are a meeting of the minds and serve a range of purposes. They are where discussions on innovative ideas occur, enabling experts to explain and exchange information to address a problem. Conferences can be academic, where scientists or academics gather to present research findings or conduct workshops on particular topics (Achakulvisut et al., 2020). The traditional conference format presents the results of research already undertaken to attendees who consume that knowledge by listening to research presentations (Davis and Pechmann, 2013). However, there has been growth in a different style of conference, the dialogical conference (Ozanne, 2011). The social construction of dialogical conferences occurs through a discursive approach, that is, they take an inductive, realist approach (Hunt, 2013; 2020), formed around discussions aimed at solving a specific problem (Clifton, 2012), where the generation of ideas occurs at the conference. There is further development of these new ideas after the conclusion of the conference, often resulting in the publication of manuscripts in special issues and special sections (see for example Block et al., 2011; Davey et al., 2019; Davis and Pechmann, 2013; Gallan et al., 2019; Kennedy et al., 2017; Parkinson et al., 2017). As noted by Anderson and Ostrom (2015), dialogical conferences offer potential for service researchers to solve complex problems, through meaningful engagement and collaboration of all participants to generate new theoretical and practical perspectives for generating solutions. There are 
growing calls for marketing research to develop more inductive, realist approaches to theory development (Hunt, 2012; 2013; 2020) and service solutions to complex problems (Anderson et al., 2013; Ostrom et al., 2010; Ozanne et al., 2017), to improve human welfare (Rosenbaum, 2015; Rosenbaum et al., 2011) and develop inclusive services (Fisk et al., 2018). In response, this paper explores the dialogical conference as a route to undertake meaningful work with practical and societal solutions as called for by Mick,(2006) and Davis and Pechmann (2020).

This viewpoint paper backgrounds the development of the dialogical conference, develops a framework for understanding the social construction of the dialogical conference, and provides research priorities for further developing the practice in the services marketing discipline. To do so, we first offer three perspectives on knowledge generation in services marketing from the vantage point of value co-creation:

(i) Conferences are a meeting of the minds bringing together people to disseminate research on particular topics or in particular contexts. After understanding this, the next step is to make it specific to solving complex problems, for example, a services context. Transformative Service Research and Transformative Consumer Research both seek to conceive and design solutions to consumer and service entities' complex problems. Thus, conferences are increasingly significant in scholars being responsive to solving the most complex problems through behaviour change and service offerings. Brodie (2017) supports this notion that to be responsive to the rapidly evolving market place, academics and practitioners, including those in services marketing need to adopt new approaches to generating knowledge (Davis and 
Pechmann, 2013) that acknowledge the complexity of societal and service problems (Anderson and Ostrom, 2015; Ozanne et al., 2017; Parkinson et al., 2016).

(ii) The world is complex with increasingly complex and wicked problems.

Conferences follow a traditional format with a paper submitted first, then delegates discuss previous work, with limited or no opportunity for discussion to further develop the idea or integrate others' ideas, perspectives, or thinking (Davis and Pechmann, 2013) apart from incorporating reviewer feedback. To be responsive to the fast-changing and complex interactive service marketing space, we need interactive conferences that seek to address these limitations.

(iii) Dialogical conferences can help us be responsive and appreciate wider and different perspectives (e.g. an inductive approach to co-creation of a manuscript), and process the complexity of the phenomena presented (Ozanne, 2011). Dialogical conferences, through the use of collective intelligence and perspectives, allow a faster development of solutions to real problems than in traditional conferences by participants brainstorming and co-creating innovative solutions and outcomes.

\subsection{Connecting social constructionism and dialogical conferences}

Hastings et al. (2019) call for scholars to be explicit about the tenets of their theory and to define its entities and relations within the theory in order to allow comparisons with other theories. Responding to this, we connect the entities of value co-creation (value coproduction and value-in-use) with interactive engagement platforms (artifacts, persons, processes and interfaces) to demonstrate the theoretical contributions of the proposed framework of dialogical conferences as a value-co-creation service. 
Due to the interactive nature of dialogical conferences and the interaction of individuals, they are socially constructed.

Blumer (1969) presented three principles for the study of social reality: people act towards objects based on the meanings these objects hold for them; the meaning of the object is negotiated through social interaction; and because the meaning of objects is subject to people's interpretive processes, meaning is variable. These principles guide the development of the proposed framework. In doing so, we draw on two complementary approaches to conceptualising value co-creation, value-in-use and value co-production (Ranjan and Read, 2016) and the artifacts, persons, processes and interfaces (APPI) framework (Ramaswamy and Ozcan, 2018). The theoretical framework (Figure 2) emerged from the authors' experiences at several dialogical conferences.

\section{Dialogical Conferences}

\subsection{What are dialogical conferences?}

A conference is an opportunity for our academic community to gather, share insights, build and renew social ties and research commitments (Mair and Frew, 2018). These academic gatherings are often engaging opportunities from which researchers leave motivated and inspired to continue their research. However, as these gatherings have grown in size, small circles of academics inevitably gravitate together, making it difficult particularly for early career researchers to penetrate the boundaries of these social networks that are so important to academic success and the development of new generations of scholars. Moreover, traditional conferences rely on one-way communication, in which expert scholars disseminate research findings to audiences. This consigns two-way academic exchange, the giving and 
taking of thoughts and ideas, to a short moment of questions and answers at the end of a session. Given the time constraints of these settings, exchanges are frequently condensed and fractured in focus. Frequently, scholars leave this academic feast strangely hungry for a more extensive exchange (Ozanne, 2011). While a traditional conference invites scholars and practitioners to present past research to conference delegates who consume that knowledge by listening to presentations, the dialogical approach invites scholars to gather in smaller, focused groups and engage in intensive discussions about their topic areas.

Conversely, a dialogical conference offers scholars with different levels of experience the opportunity to come together to exchange ideas in a less formal and supportive environment. If co-creation in services, as a relatively new academic movement, is going to succeed, leveraging the experience of senior researchers who have been working on a range of social problems for years is important. Moreover, these research communities must create a comfortable home for new scholars and welcome them into this social network of experience. This interactive dialogue assists in ensuring the passing on of vast knowledge to the new generation of researchers.

Interactive dialogue focused on a common purpose is a good way to forge ties, exchange insights and develop new ideas. Interactive dialogue involves multidimensional exchanges in which researchers are encouraged to think broadly rather than remain within the boundaries of their own silos of expertise. Furthermore, dialogical conferences offer the opportunity to advance the substantive area of interest by building common understandings, connecting theoretical approaches, and, when incommensurable differences exist, cultivating an appreciation for these differences. Dialogical conferences include all participants who work cooperatively to explore complex and difficult to define topics using the principles of 
democratic dialogue (Gustavsen, 2001; Ozanne et al., 2011) Dialogical conferences offer a broader, more expansive form of understanding, needed to comprehend social problems and chart a course forward, and the forging of action plans in complex interdependent settings.

\subsection{Origins of dialogical conferences: democratic dialogue:}

The dialogical conference is a collective, interactive process, with the guiding principles of democratic dialogue (Gustavsen, 1992). Democratic dialogue has its origins in action research based on inter-organizational learning and development through social constructionism, dialogue and pragmatism to develop change and development processes (Gergen and Thatchenkery, 1996; Gustavsen, 1992). Knowledge, seen as shared understanding generated by developmental action (Ford and Ogilvie, 1996; Huzzard, 2000) involves procedural knowledge around the process of organising change and declarative knowledge of the content for understanding the formation of solutions (Ekman-Philips and Huzzard, 2007).

The dialogical conference, used successfully in Scandinavia for some 30 years, is useful as a developmental tool, and has diffused well beyond the Nordic frontiers (Naschold, 1993). The basic ideas behind dialogical approaches in organisational transformations to problems are to develop communicative competence within organizations and mobilise a broad level of participation by employees in developmental activities through creating a public arena for communication. In the context of organisational behaviour, employees take part from agreed principles for good communication based on Habermas' (1987) idea of free communication (McCarthy, 1996). Democratic dialogue principles can be briefly summarised as increasing individual agency, a process of give and take, the expression of individual interests that 
merge into a future vision of the group, and a process that enhances trust and commitment (Kalliola et al., 2019).

One way to democratise the research process is to collaborate with a diverse array of participants, to study issues that are of greatest relevance to those who are most ignored. In this way, the distribution of power can benefit of all researchers within the group. Such collaborations could influence critical initial research decision making such as topic selection, hypothesis formation, contextual choice, and priority groups of consumers on which to focus (Davis and Ozanne, 2019). For example, a group of transformative consumer researchers, Block et al. (2011) considered ways to encourage consumers to make healthier food choices beyond the traditional approaches which focus on calorie counting and avoiding unhealthy food. As a result, this group of researchers reconceptualised "food as health" to "food as well-being." The paper is highly cited, particularly in non-marketing journals, and the National Academies Press of the National Academy of Sciences of the Congress of the United States make reference to this paper.

\subsection{Dialogical conference process}

The dialogical conference method therefore combines two important principles, that is, a stimulation of collaboration on change issues and second, an expansion of conversational involvement. Dialogue is the process through which to bridge the gap between individual and group learning through a discursive approach (Wilkinson and Kitzinger, 2000). The discursive approach enables the social construction of a shared narrative, through the generation of insights into the topic of interest (Clifton, 2012). The dialogical conference intends to generate dialogue as a precursor to social change activities from within the special interest group itself rather than rely on the "expertise" of those from the outside. This is 
consistent with the approach suggested by (MacInnis, 2011) that idea generation helps us to better understand a concept, problem or solution, rather than relying on the established literature. Thus, the dialogue comprises elements of learning and exchanges of knowledge derived from the experiences of those present.

Typically, the structure of a dialogical conference takes the format of successive group conversations, each followed by presentations to the group and in many cases, the development of a manuscript. These conversations can occur, prior to or post conference, or both. These group conversations usually encompass four themes including, visions, challenges, ideas and plans for the future. This discursive approach provides a method for facilitating extended exchanges among the participants through creating symmetry between them in terms of contributing to, and arranging the conversation to stimulate participation. The discursive approach also is an opportunity for various dimensions of learning, for instance listening, making oneself understood, taking part in democratic talk, and learning how to learn. Importantly, the dialogue implies a collaborative opportunity for collective learning and contribution to knowledge.

The notion of being "democratic" has a connection to the right and commitment of all concerned to participate in the dialogue (Gustavsen, 2016). Thus, the dialogue assumes a respect for experiences, equivalent to that of expert knowledge, as a basis for new and more expansive knowledge (Engelstad, 1996; Gustavsen, 1992; Kalliola et al., 2019; $\mathrm{Pa}^{\circ}$ 1shaugen, 2001; Shotter and Gustavsen, 1999). However, there is always the underlying issue of academics with more experience and while there is an argument that this should be a supportive environment, there is a key role for more senior/experienced participants to play in developing an equitable environment. They need to be prepared to relinquish some seniority 
to establish equality in the group. There is also the opportunity for them to provide key insights and keep the dialogical process moving. Further, they have the opportunity to mentor and encourage more junior/less experienced participants.

Dialogue as a democratic mechanism is dependent on four conditions. First, individuals need to have the necessary resources to participate. Fundamentally, this means the necessary work experiences or, using value co-creation terminology, the interactive agencies of the actors (Ramaswamy and Ozcan, 2014, 2018). Secondly, there must be arenas or platforms where the participation can take place, that is, there is a need for creation of frameworks for communication in various arenas. Thirdly, attempts to improve the conversational situations by putting into practice ground rules for good communication. The quality of the communication is of central importance. Finally, the participants should view both the working forms and themes as appropriate - shared views. Furthermore, we also acknowledge the dimension of positionality, in this context referring to the relative positioning of group members in relation to their personal and professional networks, their expertise, and their institutions, which creates unequal power relationships within a dialogical group (Merriam et al., 2001).

\section{Dialogical conferences as a value co-creation service}

The playing out of a dialogical conference concerns above all, a coming together of people with the opportunity to converse on topics seen as important. This can be an event without any apparent formality, but this "talking together" infuses the conference participants with the feeling of experiencing a transformation. A dialogical conference is fundamentally about knowledge generation, created by the integration of skills and knowledge (operant resources) of the participants in the interactions facilitated by the conference (Vargo and Lusch, 2004). 
Thus, dialogical conferences are important not only from an academic perspective but also because of their potential contribution to society in solving problems through knowledge generation. Dialogical conferences identify a practice-based gap, that is, a problem that needs a solution, rather than a theory-based gap, to enable researchers to come up with real world solutions to some of the 'gnarly' issues facing service researchers.

Ranjan and Read (2016) conceptualise the core of value co-creation as comprising two dimensions: value co-production and value-in-use. Co-production is then theorised as comprising a set of activities characterised by cooperation, dialogue, and mutual exchange (Arvidsson, 2011; Grönroos, 2012; Ordanini and Pasini, 2008) that integrates mutual resources into value. Although the predominant locus of control in co-production is the firm, consumers are committed and involved to varying degrees. Ranjan and Read (2016) then categorise co-production into knowledge sharing, equity, and interaction. Knowledge sharing between consumer and firm is the sharing of "accumulated previous learning, ideas, creativity, and real-life situations and roles" (Ranjan and Read, 2016, p. 292) that enables improved need evaluation and creativity in meeting those needs, thus co-creating value. Equity concerns the sharing of the firm's control and providing the enabling environment for consumer empowerment and contribution. The importance of equity in resource integration and value co-creation is its focus on the attributes of openness, mutual exchange, and congruence of interests (Arvidsson, 2011; Ordanini and Pasini, 2008). However, the focus of these attributes is from the firm's perspective. Thirdly, interaction through participation, dialogue, and engagement is the "primary interface between parties undertaking coproduction" (Ranjan and Read, 2016, p. 293) making possible new value-creating service solutions. 
Value-in-use, the second dimension of value co-creation, is "derived from the user's use context and processes" (Ranjan and Read, 2016, p. 293). This goes beyond the functional attributes of a service or product and involves the experience of value in the use of that service or product. Ranjan and Read (2016) identify three categories of value-in-use: experience, personalisation and relationship. The consumer's affective and cognitive processes from the service or product interaction creates experience in use value. Next, personalization refers to "value being contingent on individual characteristics" (Ranjan and Read, 2016, p. 294) and the unique use process and exchange of value in the interaction between consumer and firm. The third category, relationship, creates value through "joint, reciprocal, and iterative processes" (Ranjan and Read, 2016, p. 294), by which there are connected activities that integrate resources (Archpru Akaka and Chandler, 2011).

Viewed as a co-creation service, dialogical conferences result in varying value outcomes. While value co-production elements are functional compared with value-in-use being experiential, Gummerus (2013) argues that co-creation takes place when the participants all benefit (perceive they are better off), willingly participate in the dialogical activities, and, importantly, acknowledge their and the other participants' roles in co-production and valuein-use activities. By explaining and visualising the dialogical conference as a value cocreation service, we propose that the processes dimension of value-in-use has complex layers underexplored in other contexts - namely, the enabling condition of equality without which the other process elements could not have functioned successfully. Here, we note that in dialogical conferences "mutuality of expectations does not always insinuate equality of participation" (Miller and Hafner, 2008, p. 104). The attributes of openness and mutual interests that define equity in value co-creation may overlook possible differences in participation, involvement, and influence in dialogical discussions. By contrast, the condition 
of equality in dialogical interactions allows views to be discussed and merged, positionality to be accommodated, and strengths to be built on (weaknesses or limitations supported). Equality, as distinct from equity, refers to equal contribution, attribution and ownership with respect to the dialogue and the collaborative processes in dialogical interactions. The idea of equality underpinning dialogical interactions is that all individuals have equal opportunity to contribute and there is equal opportunity for transformation and value co-creation (Flecha, 2000).

The framework (Figure 1) highlights the importance of both equity and equality for a socially constructed conference that has valuable outputs, for example, a journal manuscript, ongoing productive research partnerships, and extended knowledge generation and understanding. 
Figure 1. Theoretical framework of a dialogical conference as a value co-creation service

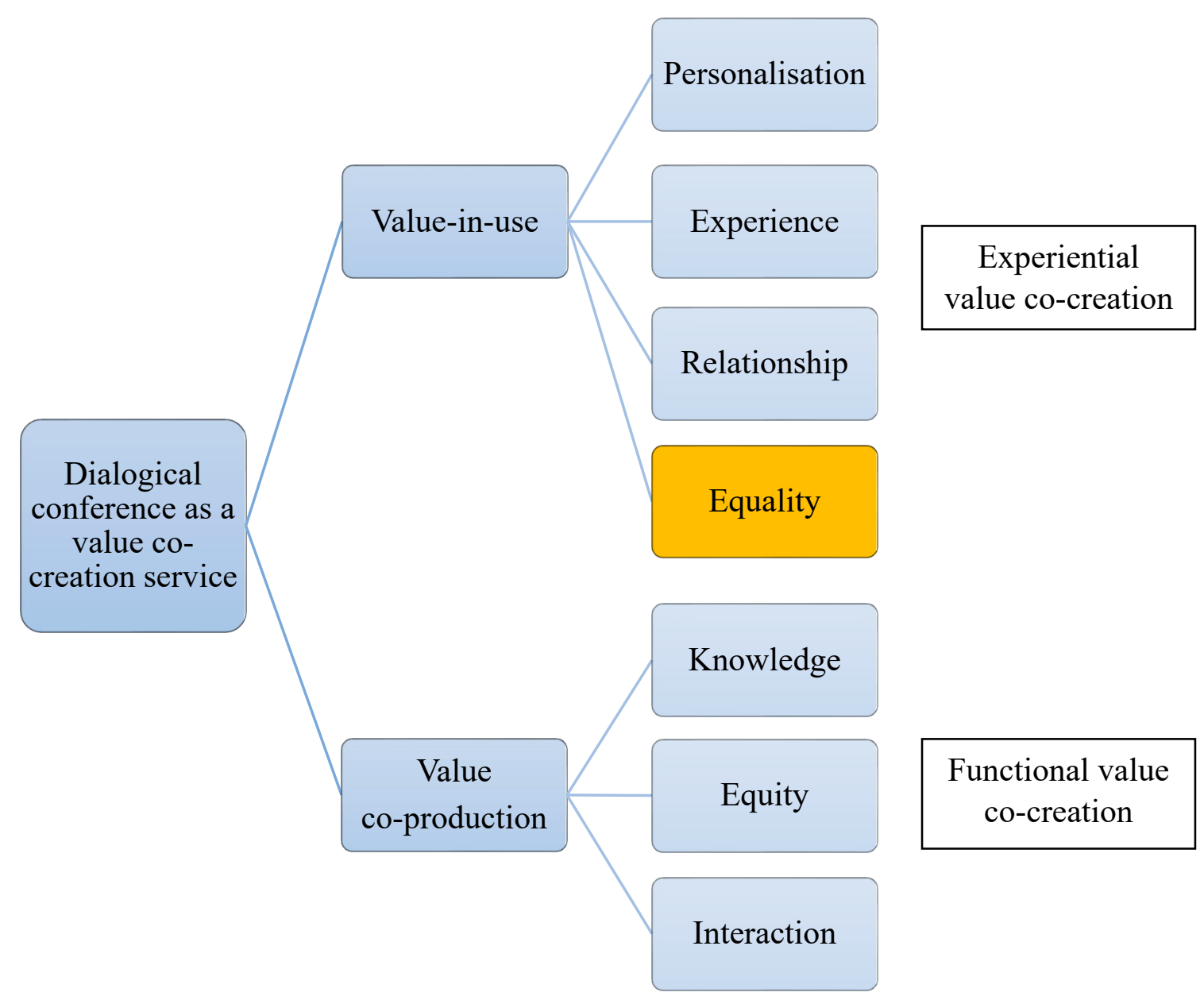

Ranjan and Read's (2016) value co-creation dimensions and categories

New value-in-use category 
This framework first represents elements of dialogical conferences in terms of value cocreation outcomes (Hastings et al., 2019). This allows us to approach value co-creation in dialogical conferences as not only knowledge generation (growing the mind) but potentially as capacity building and developmental (growing the person) by creating meaning and value. As service researchers and marketing academics experiment with new approaches and engage in new interaction spaces in dialogical conferences, they may build new networks for future collaborations (Hixson, 2012) and adopt a wider range of roles to carry out high quality research (Rogers, 2013). Hixson (2012) goes as far as to highlight the possibility that such encounters at conferences may even increase job satisfaction and improve performance, because meeting face to face allows people to get to know each other on a more personal level, and thus leads to better cooperation and collaboration).

Considering the engagement platform as the interrelated aspects of the structural context (artifacts and interfaces) with aspects of people and processes, such as efficacy, competency, freedom, and choice (Anderson et al., 2016), actors interact to create experiential and functional value outcomes. This engagement platform in dialogical conferences is considered next.

\section{Value Co-creation Engagement Platform: artifacts, persons, processes, interfaces}

Value co-creation as the "...interplay between interactive agencies of actors and networked structure of interacting system environments" (Ramaswamy and Ozcan, 2018, p. 201) is used here to understand how dialogical conferences are a value co-creating service. Specifically, we arrange the process using Ramaswamy and Ozcan $(2014,2018)$ conceptualisation of engagement platforms comprising artifacts, persons, processes and interfaces (APPI) to further understand the applicability of co-creation to our own endeavours. The platform of the 
dialogical conference and the components enable participants to work together and assist each other, to co-create value and to instigate effective networks (Tiwana, 2015). Our purpose is to reflect on the application of the much-discussed co-creation paradigm to a familiar experience so as service marketers we can better identify, interpret and facilitate cocreation. This will potentially lead to better outcomes including journal manuscripts, and research collaborations that satisfy the needs and goals of participants Additionally, Hixson (2012) argues these conference encounters also have the potential to increase job satisfaction and improve performance, leading to better cooperation and collaboration. The value cocreation engagement platform also offers significant potential for service marketers to conceive and design solutions to human service system challenges. 
We introduce the characteristics of the engagement platform before discussing the four APPI elements. The first level/ phase of the engagement platform is the specific dialogical conference, which later evolves to processes of leveraging members' resources and capabilities to generate knowledge using digital interfaces. Collectively, these elements of the engagement platforms, are designed to "engage different stakeholders around their individual domains of experiences". (Ramaswamy and Ozcan, 2014, p. 32). The engagement platform is described according to characteristics of intentionality, integrativity, creativity, and transformativity.

First, intentionality. The conference organisers provide a structuring organisation in the physical environment and conference programme, but also in the processes of group formation, combining capabilities and experiential resources of group members with the members' stated goals and research interests. This intentionality pays dividends in that it facilitates initial ideation, fosters common purpose, and makes explicit shared motivation. For example, at a services dialogical conference, group members sharing a social marketing and transformative service ideology that allows them to leverage group members' experiential knowledge to develop an achievable research purpose on which to build the cocreation endeavour. At the same time, in order to enable the intention of the group (which could be different to just the collection of individual interests), the members need to be connected by information flows, control processes (deadlines, tasks, task boundaries), and functional processes (Zoom, Skype, Dropbox) that allow communication and coordination. These processes help achieve the second aspect of integrativity. Ramaswamy and Ozcan (2014) describe the third characteristic, creativity, as opportunity for action that arises from (among other things) differences and the capacity for growth and development, that is, transformativity. The dialogical conference affords the opportunity for transformation of 
initial understanding into new insights through collaboration and individual contribution of knowledge and expertise.

At the heart of Ramaswamy and Ozcan's co-creation framework is interactional value creation focusing attention on the interplay between actors (as conference participants), resources (knowledge, abilities, positionality, and roles) and the platforms that facilitate the co-creation. Together, these are agencial assemblages within which the participants are entangled (Ramaswamy and Ozcan, 2018). The key elements of the interactional creation are: artifacts, persons, processes, and interfaces (APPI) which map onto the co-production and value-in-use attributes in Table 1 and explained below. 
Table 1. Mapping APPI value co-creation activities in dialogical conferences onto categories of value co-creation

\begin{tabular}{|c|c|c|c|c|}
\hline $\begin{array}{l}\text { Interactive } \\
\text { engagement } \\
\text { platform }\end{array}$ & Value co-creating activities & $\begin{array}{l}\text { Structural } \\
\text { resources }\end{array}$ & $\begin{array}{l}\text { Value co- } \\
\text { creation } \\
\text { categories }\end{array}$ & Source \\
\hline Artifacts & $\begin{array}{l}\text { Research, secondary data, } \\
\text { literature } \\
\text { Topic proposals } \\
\text { Conference topic } \\
\text { Participant biographies and } \\
\text { introductory presentations }\end{array}$ & $\begin{array}{l}\text { Visible and } \\
\text { tangible artifacts, } \\
\text { developed and } \\
\text { used by } \\
\text { participants. }\end{array}$ & & $\begin{array}{l}\text { Operand resources } \\
\text { (Vargo and Lusch, 2004) }\end{array}$ \\
\hline \multirow[t]{4}{*}{ Persons } & $\begin{array}{l}\text { Nurture and maintain } \\
\text { connections, disagree and } \\
\text { discuss }\end{array}$ & & Personalisation & $\begin{array}{l}\text { Value-in-use } \\
\text { (Ranjan and Read, 2016) }\end{array}$ \\
\hline & $\begin{array}{l}\text { Competences, capabilities } \\
\text { and experiences } \\
\text { Critical thinking and } \\
\text { discourse }\end{array}$ & & Experience & $\begin{array}{l}\text { Value-in-use } \\
\text { (Ranjan and Read, 2016) }\end{array}$ \\
\hline & $\begin{array}{l}\text { Shared views } \\
\text { Respect for differences, } \\
\text { respect for experience }\end{array}$ & & Relationships & $\begin{array}{l}\text { Value-in-use } \\
\text { (Ranjan and Read, } \\
\text { 2016) }\end{array}$ \\
\hline & $\begin{array}{l}\text { Equal effort/ motivation/ } \\
\text { equal contribution of } \\
\text { resources }\end{array}$ & & Equality & $\begin{array}{l}\text { New category of Value- } \\
\text { in-use }\end{array}$ \\
\hline \multirow[t]{3}{*}{ Processes } & $\begin{array}{l}\text { Pre-reading work } \\
\text { In-conference } \\
\text { presentations of developed } \\
\text { work } \\
\text { Post-conference publications } \\
\text { or grants beyond conference } \\
\text { topic } \\
\text { Manuscript publication on } \\
\text { conference topic }\end{array}$ & & Knowledge & $\begin{array}{l}\text { Value co- } \\
\text { production } \\
\text { (Ranjan and Read, 2016) }\end{array}$ \\
\hline & $\begin{array}{l}\text { Project management } \\
\text { Sharing control } \\
\text { Group membership } \\
\text { determined by workshop } \\
\text { organisers }\end{array}$ & & Equity & $\begin{array}{l}\text { Value co- } \\
\text { production } \\
\text { (Ranjan and Read, 2016) }\end{array}$ \\
\hline & $\begin{array}{l}\text { Collaborative ground rules } \\
\text { Tasks } \\
\text { Roles }\end{array}$ & & Interaction & $\begin{array}{l}\text { Value co- } \\
\text { production } \\
\text { (Ranjan and Read, } \\
\text { 2016) }\end{array}$ \\
\hline Interfaces & $\begin{array}{l}\text { Physical and digitalised } \\
\text { interfaces } \\
\text { In-conference sessions } \\
\text { Skype/Zoom/Dropbox }\end{array}$ & $\begin{array}{l}\text { Multiple points of } \\
\text { connection } \\
\text { offering } \\
\text { communication, } \\
\text { and decision- } \\
\text { making. }\end{array}$ & & $\begin{array}{l}\text { Operand resources } \\
\text { (Vargo and Lusch, 2004) }\end{array}$ \\
\hline
\end{tabular}




\subsection{Structural resources: Artifacts}

In this conceptualisation of co-creation, artifacts include "physical and digitalised things, including data in the form of numbers, text, pictures, audio, and video" (Ramaswamy and Ozcan, 2018, p. 198). Artifacts include existing literature, secondary data, and research findings on the agreed topic of interest. Other indirect artifacts that are also useful for informing the dialogical conference are presentations and participant biographies in the conference programme. For example, textual records of social marketing cases have been the catalyst for dialogical group discussion and formulation of research ideas in microfoundations of preventive health behaviours (Davey et al., 2019), food systems compass (Parkinson et al., 2017) and community wellbeing (Gallan et al., 2019). The process of cocreating the manuscript subsequently relied on considerable textual and numerical data as artifacts in developing the research, progressing the contribution to knowledge to final manuscript submission and acceptance.

\subsection{Value-in-use Attributes: Persons}

The Persons element of an engagement platform refers to "individuals in their roles as customers, employees, partners, and any other stakeholders" (Ramaswamy and Ozcan, 2018, p. 198) and their interactions, paralleling Ranjan and Read's (2016) conceptualisation of value-in-use. Organising actors (organising actors and engaging actors) are initially the conference facilitators (as the organisation or business might be considered in the co-creation framework) and participating group members are the engaging actors (in other service contexts these persons would be the customers). As the group evolves, roles and tasks are allocated and adopted to develop the research idea, identify expertise (expert resources), and plan the co-production activities. These organising and engaging actors' roles are dynamic as views, values and beliefs emerge and integrate in relation to the research process and the 
research topic. These roles are critical to value co-creation. For example, the architect or project manager needs to overcome and manage the barriers to the co-creation process, since the co-creation process can be limited if the actors do not bring or are unwilling to share their resources. Actors may be capable but are hesitant or reluctant due to positionality (Coghlan and Brydon-Miller, 2014) or perceived value of their resources.

Competences, capabilities, and experiences of the group members are organised and integrated by the other APPI elements. Research competences in appreciating the relevant body of knowledge, conceptualising and designing the research, data collection synthesis, and interpretation of data, come together in the engagement platform.

\subsection{Value Co-Production Attributes: Processes}

Processes include "digitised and more conventional business processes of interactions" (Ramaswamy and Ozcan, 2018, p. 198). In a dialogical conference, processes are purposefully designed and structured according to certain ground rules. The structuring of processes using prior experience and expertise, at the same time designing processes that adjust to the evolving research process and dialogue is critical to the co-production activities (Kollenscher et al., 2009).

These processes combine and interact with the other parts of the co-creation assemblage, for example, the processes for managing actor roles and responsibilities impact the quality of the group relationship and the democratic dialogue, thus shaping the dialogical interaction.

Firstly, there are processes that set up the group functioning, negotiation of the topic and brainstorming the group research task. There are agreed processes for achieving the task and communication methods. The group creates a joint plan, tasks are separated and allocated 
according to individual skills - for example, a task-oriented leader is chosen, another group member takes notes while another may begin a literature search, and another develops a mind map for the research topic. The processes serve to legitimise the authority of the group leader and an acknowledgement by all group members of others' roles and responsibilities. Agreeing to authorship order is also important in this process to establish shared understanding of the expectations at the start of the process. These processes therefore explicitly address "the structural power inequalities and privileges people inevitably bring to dialogical spaces" (Suransky and Alma, 2018, p. 34) and minimise incompatibility.

\subsection{Structural resources: Interfaces}

As a structural attribute for the value co-creation interaction, dialogical conferences use physical and digitalised interfaces by which the actors interact with other actors, engage in the processes, and utilise the various artifacts to facilitate the democratic dialogue. Marketing conferences and symposia draw on global participants. Thus, DeLanda's (2006) notion of copresence is enabled through various forms of communication and virtual co-presence. Virtual co-presence is often initiated in advance of the physical interface of the dialogical meeting. Similarly, the dispersion of participants from the dialogical meeting place means that virtual online platforms are used to collaborate and develop the group's purpose - Zoom, Skype, Dropbox, email - after the physical interface has concluded. These interfaces facilitate the activities to be enacted that result in the value-in-use and value co-production outcomes (refer Table 1 and Figure 2). They are the planned and purposeful infrastructure through which the dialogical processes occur and group members experience value by carrying out high quality research and building their collective capacity as academics. In dialogical value co-creation rather than the firm being the locus of control, the locus of control is the group membership. 
Aligned with democratic dialogue, the more inclusive the engagement of the participants in the act of creating value, the better the results (Ramaswamy and Ozcan, 2014).

\section{Conceptualising the framework of dialogical conferences as a value co-creation service}

Drawing together the value-in-use and co-production outcomes of dialogical conferences and mapping these onto the APPI activities, we propose a framework for dialogical conferences as a value co-creation service (Figure 2). This framework is applicable to smaller dialogical groups as well as conference workshops. For example, the framework helps explain the processes of value co-creation when a group of scholars conceptualise a paper, undertake research, contribute to knowledge at the same time building relationships, capacity, agency and resources for future knowledge generation and understanding. Following this dialogical process enables both functional and experiential value outcomes.

Through examining the collaborative and participatory platforms for engagement in dialogical conferences we also propose an extra category of value-in-use, equality that has applications in other service contexts and service research. We also provide practical and implementable insights into the activity of value co-creation in dialogical conferences. 
Figure 2. An integrated framework of dialogical conferences as a value co-creation service

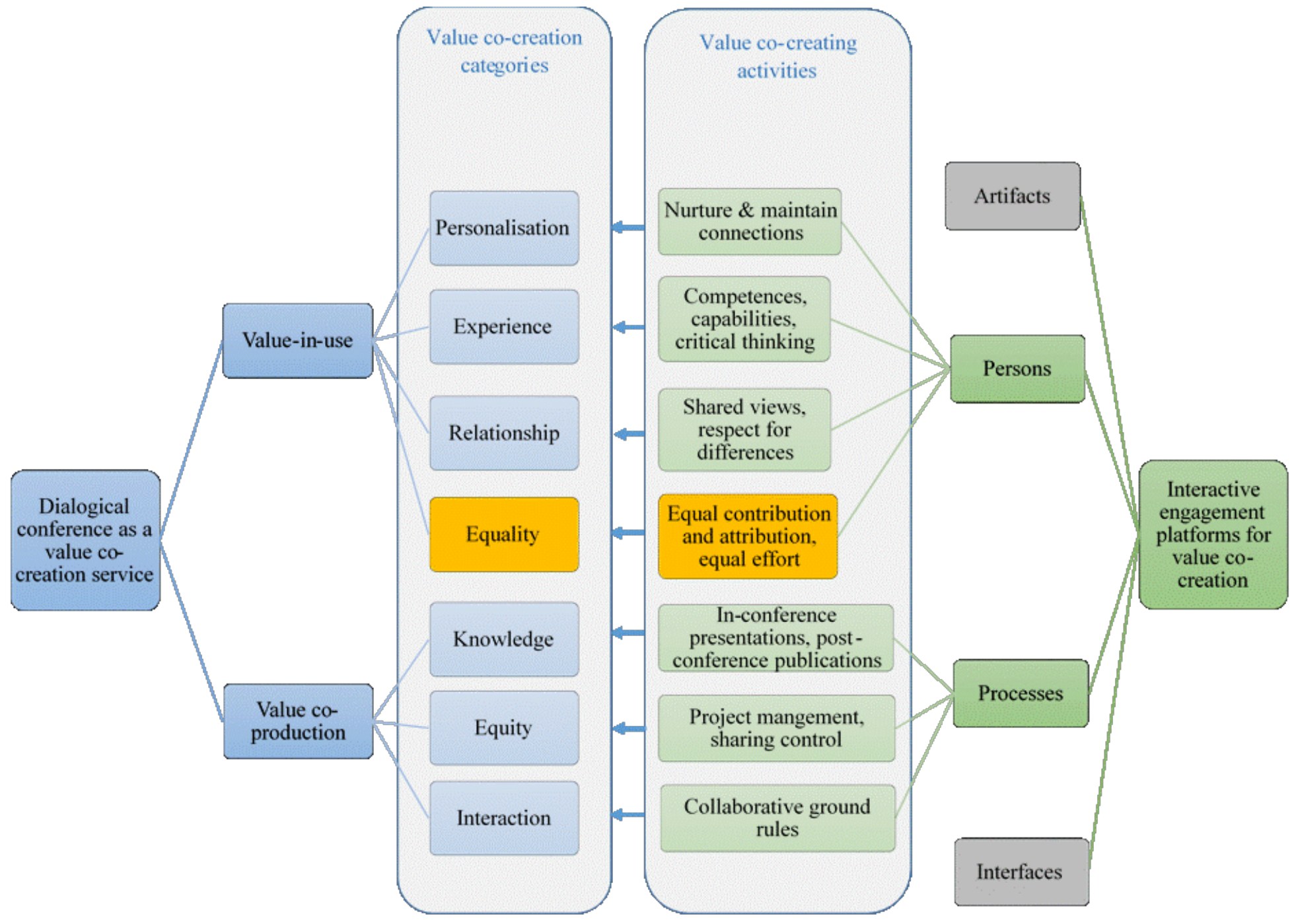

Ranjan and Read's (2016) value co-creation dimensions and categories

New value-in-use category and APPI activities in dialogical conference value cocreation

Interactive engagement platform elements and activities in dialogical conferences

(Ramaswamy and Ozcan, 2014, 2018)

Structural resources for interactive engagement platforms in dialogical conferences

(Ramaswamy and Ozcan, 2014, 2018) 


\section{Research Priorities for dialogical conferences}

This paper has presented dialogical conferences as a value cocreation service as called for in order to develop new approaches for generating new theory, knowledge and impact (Anderson and Ostrom, 2015; Brodie, 2017). This paper demonstrates how we usefully bring service logic to bear with a dialogical conference to help us extend our knowledge and we can use our discipline knowledge or theory to co-create solutions to real world problems. To further develop this, we pose a number of research priorities to further understand value co-creation in dialogical conferences that will allow us to extend our discipline knowledge and/or theory and to co-create solutions to real world problems. The following research priorities are developed based on the APPI framework of value co-creation.

APPI framework-based research priorities:

(1) Artifacts - Structural resources for value creating activities

- What are the preconditions for value co-creation in dialogical groups?

- What are outcomes for participants?

- How are artefacts structured, designed and implemented for dialogical value cocreation?

- How do dialogical conferences help solve real world wicked/social problems?

- How does a dialogical conference nurture existing research relationships, and/or develop new ones, to create new knowledge and understanding?

(2) Persons

Value-in-use category: Personalisation

- What activities enhance value-in-use for members?

- How do task roles leverage off different perspectives and paradigms for value coproduction and value-in-use? 
Value-in-use category: Experience

- What are the enabling and constraining factors for effective role allocation, to facilitate best use of competences and skills in dialogical conferences?

- How is positionality managed to facilitate joint value co-creation?

- How are differing viewpoints, paradigms, ideologies embedded or accommodated in dialogical conferences?

- How do participants navigate being exposed to different paradigms and viewpoints within the same dialogical group?

- How are different perspectives integrated into the outputs such as journal manuscripts?

Value-in-use category: Relationships

- How do conference leaders facilitate connections?

- How does change and perception of uncertainty (as the task purpose shifts) influence co-production and value-in-use?

- What/how are social networks built/influenced as a result of the dialogical conference? How does career stage, early career research and mid-career research, influence social network development?

- What types of relationships are built or avoided?

- How long do these relationships last?

- What are lessons learned around relationships built at DC?

- Is it academic knowledge versus personal knowledge? Ways of doing things, ways of looking at things. Extending your horizons in terms of discipline?

Value-in-use category: Equality

- What/How can processes minimise the effects of power imbalances brought by academic scholars to dialogical conferences? 
- How can negative effects of privileges be minimised in dialogical groups?

(3) Processes

Value Co-production category: Knowledge

- How is knowledge shared within and beyond the group?

- How does pre-reading or pre-work enhance or inhibit knowledge sharing within the group?

Value Co-production category: Equity

- How can processes minimise the effects of power imbalances brought by academic scholars to dialogical conferences?

- How can negative effects of privileges be minimised in dialogical groups?

Value Co-production category: Interaction

- How are ground rules effectively implemented, accommodating diverse dialogical groups?

- How is stability in working teams achieved across time and conferences?

- Is the replication of group membership valuable or not?

- Roles enable participants to integrate resources. How does role readiness enhance or constrain value co-creation in dialogical conferences?

- How are tasks allocated for value co-creation?

(4) Interfaces - Structural resources for value creating activities

- How do interfaces enable and constrain value co-creation?

- How are the interfaces sequenced (pre-, during, and post-dialogical conference) to facilitate functional outcomes and value-in-use outcomes? 


\section{Implications and concluding remarks}

In response to the challenge for service researchers to develop new approaches for generating new theory, knowledge and impact (Anderson and Ostrom, 2015; Brodie, 2017; Davis and Pechmann, 2013), we have presented a set of research priorities based on the APPI framework. The presented framework condenses the phenomenon of co-creation through collaborative and participatory platforms for engagement of academics and practitioners, facilitating democratic dialogue in order to solve real world social and wicked problems. This framework can be adapted for developing and designing transformative service research and transformative consumer research using a collaborative approach to solving problems. We encourage service marketing scholars and practitioners to adopt this approach as it provides an impact pathway through the co-creation of submissions for the individual (micro level) and knowledge generation for the discipline (meso level) and implementable solutions at the macro level for the wicked problem. These activities, which lead to outputs (individual) then lead to outcomes (meso) which eventually lead to impacts (macro). The contribution of a dialogical approach is new knowledge generation and capacity for practical action which responds to both individual and organisational needs and value. In addition to generating outcomes including journal manuscripts, other potential outcomes from dialogical conferences include research collaborations, the potential to increase job satisfaction and improve performance, leading to engagement and collaboration to create impactful service solutions.

The platform of the dialogical conference and the components enable participants to work together and assist each other, to co-create value and instigate effective networks. Operationalising dialogical conferences through a value co-creation lens, provides a tool to enable service marketers to better identify, interpret and facilitate co-creation of effective solutions. Thus, adopting this approach will enable service researchers to develop approaches 
for generating new theory, knowledge and impact to solve complex human service system problems.

\section{References}

Achakulvisut, T., Ruangrong, T., Bilgin, I., Van Den Bossche, S., Wyble, B., Goodman, D. F., \& Kording, K. P. (2020), “Improving on legacy conferences by moving online”, Elife, Vol. 9. DOI:10.7554/eLife.57892

Anderson, L. and Ostrom, A.L. (2015), "Transformative service research: advancing our knowledge about service and well-being", Journal of Service Research, Vol. 18 No. 3, pp.243-249.

Anderson, L., Ostrom, A.L., Corus, C., Fisk, R.P., Gallan, A S., Giraldo, M., ... \& Shirahada, K. (2013), "Transformative service research: an agenda for the future", Journal of Business Research, Vol. 66 No. 8, pp.1203-1210.

Anderson, L., Spanjol, J., Jefferies, J.G., Ostrom, A.L., Nations Baker, C., Bone, S.A., ... and Rapp, J.M. (2016), “Responsibility and well-being: resource integration under responsibilization in expert services", Journal of Public Policy \& Marketing, Vol. 35 No. 2, pp.262-279.

Archpru Akaka, M. and Chandler, J.D. (2011), "Roles as resources: a social roles perspective of change in value networks", Marketing Theory, Vol. 11 No. 3, pp.243-260.

Arvidsson, A. (2011), "Ethics and value in customer co-production", Marketing Theory, Vol. 11 No. 3, pp.261-278. 
Block, L.G., Grier, S.A., Childers, T.L., Davis, B., Ebert, J.E., Kumanyika, S., ... and Pettigrew, S. (2011), "From nutrients to nurturance: a conceptual introduction to food well-being", Journal of Public Policy \& Marketing, Vol. 30 No. 1, pp.5-13.

Blumer, H. (1969), Symbolic Interactionism: Perspective and Method. Prentice-Hall, Englewood Cliffs, NJ.

Brodie, R.J. (2017), "Enhancing theory development in the domain of relationship marketing: how to avoid the danger of getting stuck in the middle", Journal of Services Marketing. Vol. 31 No. 1, pp. 20-23.

Clifton, J. (2012). “A discursive approach to leadership: doing assessments and managing organizational meanings", The Journal of Business Communication (1973), Vol. 49 No. 2, pp.148-168.

Coghlan, D. and Brydon-Miller, M. (2014), The SAGE Encyclopedia of Action Research. Sage, Thousand Oaks, California.

Davey, J., Herbst, J., Johns, R., Parkinson, J., Russell-Bennett, R. and Zainuddin, N. (2019), "The role of health locus of control in value co-creation for standardized screening services", Journal of Service Theory and Practice, Vol. 30, pp.31-55.

Davis, B. and Ozanne, J.L. (2019), "Measuring the impact of transformative consumer research: the relational engagement approach as a promising avenue", Journal of Business Research, Vol. 100, pp.311-318.

Davis, B. and Pechmann, C. (2020), "The characteristics of transformative consumer research and how it can contribute to and enhance consumer psychology", Journal of Consumer Psychology, Vol. 30 No. 2, pp.365-367. 
Davis, B. and Pechmann, C. (2013), "Introduction to the Special Issue on transformative consumer research: developing theory to mobilize efforts that improve consumer and societal well-being", Journal of Business Research, Vol. 66 No. 8, pp.1168-1170.

De Landa, M. (2006), A New Philosophy of Society, Continuum, London.

Ekman-Philips, M. and Huzzard, T. (2007) "Developmental magic? Two takes on a dialogue conference”, Journal of Organizational Change Management, Vol. 20 No. 1, pp.8-25.

Engelstad, P.H. (1996), “The development organization as communicative instrumentation: experiences from the Karlstad program”, Toulmin, S. and Gustavsen, B. (Eds.), Beyond theory: changing organizations through participation, John Benjamins, Amsterdam, pp. 89-118.

Fisk, R.P., Dean, A.M., Alkire, L., Joubert, A., Previte, J., Robertson, N. and Rosenbaum, M.S. (2018), "Design for service inclusion: creating inclusive service systems by 2050”, Journal of Service Management, Vol. 29 No. 5, pp.834-858.

Flecha, R. (2000), Sharing words. Theory and practice of dialogic learning, Rowman \& Littlefield, Lanham, MD.

Ford, C.M. and Ogilvie, D.T. (1996), “The role of creative action in organizational learning and change", Journal of Organizational Change Management, Vol. 9 No. 1, pp.54-62.

Gallan, A.S., McColl-Kennedy, J.R., Barakshina, T., Figueiredo, B., Jefferies, J.G., Gollnhofer, J. ... and Winklhofer, H. (2019), “Transforming community well-being through patients' lived experiences", Journal of Business Research, Vol. 100, pp.376391. 
Gergen, K.J. and Thatchenkery, T.J. (1996), “Organization science as social construction: postmodern potentials", The Journal of Applied Behavioral Science. Vol. 32, pp.356377.

Grönroos, C. (2012), "Conceptualising value co-creation: a journey to the 1970s and back to the future", Journal of Marketing Management, Vol. 28 No. 13/14, pp.1520-1534.

Gummerus, J. (2013), "Value creation processes and value outcomes in marketing theory: strangers or siblings?", Marketing theory, Vol. 13 No. 1, pp.19-46.

Gustavsen, B. (2001), “Theory and practice: the mediating discourse”, Reason, P. and Hilary Bradbury, H. (Eds.), Handbook of Action Research: Participative Inquiry and Practice, Sage, London, pp. 17-26.

Gustavsen, B. (1992), Dialogue and development, Van Gorcum, Stockholm.

Gustavsen, B. (2016), “Democratic dialogue”, Mohr, B.J. and van Amelsvoort, P. (Eds.), CoCreating Humane and Innovative Organizations, Global STS-D Network Press, Portland ME, pp.186-200.

Habermas, J. (1987), The theory of communicative action, Polity Press, Cambridge, England.

Hastings, J., Michie, S. and Johnston, M. (2019), “Theory and ontology in building cumulative behavioural science", pp. 1-11, preprint available at OSF https://osf.io/9te3x/ (2019).

Hixson, E. (2012), “The psychological benefits of attending conventions”, paper presented at the Global Events Congress, Stavanger, Norway, June 2012.

Hunt, S.D. (2020), "Indigenous theory development in marketing: the foundational premises approach", AMS Review, 1-10. 
Hunt, S.D. (2013), "The inductive realist model of theory generation: explaining the development of a theory of marketing ethics", AMS Review, Vol. 3 No. 2, pp.67-77.

Hunt, S.D. (2012), "Explaining empirically successful marketing theories: the inductive realist model, approximate truth, and market orientation", AMS Review, Vol. 2 No. 1, pp.5-18.

Huzzard, T. (2000), Labouring to learn: union renewal in Swedish manufacturing, Lund university thesis.

Kalliola, S., Heiskanen, T. and Kivimäki, R. (2019), “What works in democratic dialogue?”, Social Sciences, Vol. 8 No. 3, pp.101-121.

Kennedy, A.M., Kapitan, S., Bajaj, N., Bakonyi, A. and Sands, S. (2017), "Uncovering wicked problem's system structure: seeing the forest for the trees", Journal of Social Marketing, Vol. 7 No. 1, pp.51-73.

Kollenscher, E., Ronen, B. and Farjoun, M. (2009), “Architectural Leadership: Building a value enhancing infrastructure", Human Systems Management, Vol. 28, pp.35-45.

MacInnis, D.J. (2011), “A framework for conceptual contributions in marketing”, Journal of Marketing, Vol. 75, pp.136-154.

Mair, J. and Frew, E. (2018), “Academic conferences: a female duo-ethnography”, Current Issues in Tourism, Vol. 21 No. 18, pp.2152-2172.

McCarthy, T. (1996), "Pragmatizing communicative reason", Toulmin, S. and Gustavsen, B. (Eds), Beyond theory: changing organizations through participation, John Benjamins, Amsterdam, pp.159-178. 
Merriam, S.B., Johnson-Bailey, J., Lee, M Y., Kee, Y., Ntseane, G. and Muhamad, M. (2001), "Power and positionality: negotiating insider/outsider status within and across cultures", International Journal of Lifelong Education, Vol. 20 No. 5, pp.405-416.

Mick, D. G. (2006), "Meaning and mattering through transformative consumer research", Pechmann, C. and Price, L. (Eds), Advances in Consumer Research, Association for Consumer Research, Provo, UT, Vol. 33, pp.1-4.

Miller, P.M. and Hafner, M M. (2008), "Moving toward dialogical collaboration: a critical examination of a university-school-community partnership", Educational Administration Quarterly, Vol. 44 No. 1, pp.66-110.

Naschold, F. (1993), “Organisational development: national programmes in the context of international competition”, in Naschold, F. Cole, R.E., Gustavsen, B. and van Beinum, H. (Eds), Constructing the New Industrial Society, van Gorcum, Stockholm, pp. 3-119.

Ordanini, A. and Pasini, P. (2008), "Service co-production and value cocreation: the case for a service-oriented architecture (SOA)", European Management Journal, Vol. 26 No.5, pp.289-297.

Ostrom, A.L., Bitner, M.J., Brown, S.W., Burkhard, K.A., Goul, M., Smith-Daniels, V., Demirkan, H. and Rabinovich, E. (2010), "Moving forward and making a difference: research priorities for the science of service", Journal of Service Research, Vol. 13 No. 1, pp.4-36. 
Ozanne, J.L. (2011), "Introduction to the Special Issue on transformative consumer research: creating dialogical spaces for policy and action research", Journal of Public Policy \& Marketing, Vol. 30, pp.1-4.

Ozanne, J.L., Davis, B., Murray, J.B., Grier, S., Benmecheddal, A., Downey, H., ... and Seregina, A. (2017), “Assessing the societal impact of research: the relational engagement approach”, Journal of Public Policy \& Marketing, Vol. 36 No. 1, pp.114.

Ozanne, J.L., Pettigrew, S., Crockett, D., Fuat Firat, A., Downey, H. and Pescud, M. (2011), "The practice of transformative consumer research - some issues and suggestions", Journal of Research for Consumers, Vol. 19, pp.1-8.

Pålshaugen, Ø. (2001), “The use of words: improving enterprises by improving their conversations", Reason, P. and Hilary Bradbury, H. (Eds.), Handbook of Action Research: Participative Inquiry and Practice, Sage, London, pp.209-218.

Parkinson, J., Dubelaar, C., Carins, J., Holden, S., Newton, F. and Pescud, M. (2017), "Approaching the wicked problem of obesity: an introduction to the food system compass", Journal of Social Marketing, Vol. 7 No. 4, pp.387-404.

Parkinson, J., Schuster, L. and Russell-Bennett, R. (2016), "Insights into the complexity of behaviours: the MOAB framework", Journal of Social Marketing. Vol. 6 No. 4, pp.412-427. 
Ramaswamy, V. and Ozcan, K. (2018), "What is co-creation? An interactional creation framework and its implications for value creation", Journal of Business Research, Vol. 84, pp.196-205.

Ramaswamy, V. and Ozcan, K. (2014), The Co-Creation Paradigm, Stanford University Press, Stanford, California.

Ranjan, K.R. and Read, S. (2016), "Value co-creation: concept and measurement”, Journal of the Academy of Marketing Science, Vol. 44, pp.290-315.

Rogers, T. (2013), Conferences and Conventions: A Global Industry, $3^{\text {rd }}$ edition, Routledge, London.

Rosenbaum, M.S. (2015), “Transformative service research: focus on well-being", The Service Industries Journal, Vol. 35 No. 7-8, pp.363-367,

Rosenbaum, M.S., Corus, C., Ostrom, A., Anderson, L., Fisk, R., Gallan, A., Giraldo, M., Mende, M., Mulder, M., Rayburn, S. and Shirahada, K. (2011), “Conceptualisation and aspirations of transformative service research", Journal of Research for Consumers, Vol. 19, pp.1-6.

Shotter, J. and Gustavsen, B. (1999), "The role of dialogue conferences in the development of learning regions: doing from within our lives together what we cannot do apart", working paper, Centre for Advanced Studies in Leadership, Stockholm School of Economics, Stockholm.

Suransky, C. and Alma, H. (2018), “An agonistic model of dialogue”, Journal of Constructivist Psychology, Vol. 31 No. 1, pp.22-38. 
Tiwana, A. (2015), "Evolutionary competition in platform ecosystems", Information Systems Research, Vol. 26 No. 2, pp. 266-281.

Vargo, S.L. and Lusch, R.F. (2004), "Evolving to a new dominant logic for Marketing”, Journal of Marketing, Vol. 68, pp.1-17.

Wilkinson, S. and Kitzinger, C. (2000), “Thinking differently about thinking positive: a discursive approach to cancer patients' talk”, Social Science \& Medicine, Vol. 50 No. 6, pp.797-811. 